\title{
INDIKASI PERUBAHAN IKLIM DAN DAMPAKNYA TERHADAP PRODUKSI PADI DI INDONESIA \\ (STUDI KASUS : SUMATERA SELATAN DAN MALANG RAYA)
}

\section{INDICATION OF CLIMATE CHANGE AND ITS IMPACT ON RICE PRODUCTION IN INDONESIA \\ (CASE STUDY: SOUTH SUMATERA AND GREAT MALANG)}

\author{
Ruminta ${ }^{1}$, Handoko ${ }^{2}$, dan Tati Nurmala ${ }^{1}$ \\ ${ }^{1}$ Program Studi Agroteknologi, Fakultas Pertanian Universitas Padjadjaran \\ ${ }^{2}$ Program Studi Agrometeorologi, Fakultas MIPA Institut Pertanian Bogor \\ Korespondensi : r_ruminta@yahoo.com
}

Diterima 14 September 2017/ Disetujui 12 Juli 2018

\begin{abstract}
ABSTRAK
Perubahan iklim telah terjadi di wilayah Indonesia. Perubahan iklim memengaruhi pertanian melalui dampaknya terhadap pertumbuhan, perkembangan, dan hasil tanaman. Penelitian indikasi perubahan iklim dan dampaknya terhadap produksi tanaman padi di Indonesia (Sumatera Selatan dan Malang Raya) pada tahun 2011-2013 telah dilakukan. Penelitian ini bertujuan untuk mengkaji adanya perubahan iklim dan bagaimana dampaknya terhadap produksi padi di Indonesia. Kajian ini menggunakan data dari temperatur, curah hujan, agroklimat, dan produksi tanaman padi serta data sosial ekonomi. Metodologi penelitian ini adalah deskriptif eksplanatori menggunakan konsep asesmen risiko dimana risiko (risk) merupakan fungsi dari bahaya (hazard) dan kerentanan (vulnerability). Hasil kajian menunjukkan bahwa di Indonesia telah terjadi perubahan iklim dengan indikasi peningkatan suhu, perubahan pola curah hujan, perubahan hitergraf, dan perubahan klasifikasi Oldeman. Hasil penelitian juga menunjukkan bahwa pertanian sangat rentan terhadap dampak perubahan iklim dengan indikasi level bahaya yang tinggi pada penurunan produksi padi sebagai akibat peningkatan suhu dan perubahan pola curah hujan. Beberapa daerah di Sumatera Selatan maupun Malang Raya mempunyai risiko tinggi pada penurunan produksi tanaman padi. Umumnya Indonesia mempunyai tingkat risiko tinggi pada penurunan produksi padi dengan rerata $1,37 \%$ per tahun dan berpotensi menyebabkan penurunan produksi pangan nasional.
\end{abstract}

Kata kunci: Bahaya, Kerentanan, Perubahan iklim, Risiko, Produksi padi

\begin{abstract}
Climate change has been occurred in Indonesia. Climate change affects agriculture through its impact on growth, development, and crop yield. Research on climate change indication and its impact on rice production in Indonesia (South Sumatra and Malang Raya) in 2011-2013 has been done. The study aimed to assess climate change and how it impacts rice production in Indonesia. This study used data of temperature, rainfall, agroclimate, and rice production and
\end{abstract}

Cyte this as: Ruminta, Handoko, \& Nurmala, T. (2018). Indikasi perubahan iklim dan dampaknya terhadap produksi padi di Indonesia (Studi kasus : Sumatera Selatan dan Malang Raya). Jurnal Agro, 5(1), 48-60. https://doi.org/10.15575/1607 
socioeconomic. The methodology of this research was descriptive explanatory using risk assessment concept where risk was a function of hazard and vulnerability. The results of the study indicated that in Indonesia has been ocurred climate change with indications of temperature increase, changes in rainfall patterns, changes in hitergraph, and changes in Oldeman classification. The results also show that agriculture is highly vulnerable to the impacts of climate change with an indication of high hazard levels in the decline of rice production due to rising temperatures and changes in rainfall patterns. Several areas in South Sumatra and Malang Raya have a high risk of decreasing the rice production. Generally Indonesia has a high risk level on the decrease of rice production with an average of 1,37\% per year and potentially causes the decline of national food production

Key words : Climate change, Hazard, Rice production, Risks, Vulnerability

\section{PENDAHULUAN}

Perubahan iklim telah dan sedang terjadi di wilayah Tropis (Manton et al., 2001; Masutomi, Takahashi, Harasawa, \& Matsuoka, 2009). Perubahan iklim memengaruhi pertanian melalui dampaknya terhadap pertumbuhan, perkembangan, dan hasil tanaman. Pertanian merupakan sektor yang sangat vital dalam pembangunan Indonesia karena lebih dari $60 \%$ dari penduduknya sangat tergantung pada pertanian sebagai mata pencahariannya (Badan Pusat Statistik, 2014). Kontribusi sektor pertanian terhadap perekonomian Indonesia akan mendapat tantangan berat akibat risiko perubahan iklim.

Perubahan iklim merupakan ancaman bagi orang yang bermata pencaharian petani tanaman padi dan mengancam ketahanan pangan suatu negara (Government of Republic of Indonesia, 2007; UNFCCC, 2007). Dampak perubahan iklim sudah menjadi kenyataan pada sektor pertanian di Indonesia (Handoko, 2007; Naylor et al., 2007). Indikasi perubahan iklim tersebut antara lain oleh adanya kenaikan suhu udara, kekeringan, bencana banjir, bergesernya musim hujan (musim hujan makin pendek) (Aldrian, 2007), peningkatan muka air laut, dan peningkatan kejadian iklim ekstrim (Ruminta \& Handoko, 2016). Dalam beberapa tahun terakhir ini pergeseran musim hujan menyebabkan bergesernya musim tanam dan panen komoditi pangan (padi dan palawija). Sedangkan banjir dan kekeringan menyebabkan gagal tanam, gagal panen, dan bahkan menyebabkan puso (Ruminta \& Handoko, 2016).

Selama abad terakhir, perubahan iklim telah menyebabkan kenaikan suhu global, pergeseran pola curah hujan, muka air laut meningkat, serta frekuensi dan intensitas cuaca ekstrim meningkat. Menurut kajian Intergovernmental Panel on Climate Change (IPCC, 2007), selama periode tahun 1899 hingga 2005 kenaikan rata-rata suhu global sebesar $0,76^{\circ} \mathrm{C}$; selama periode tahun 1961 sampai 2003 kenaikan muka air laut ratarata global sebesar $1,8 \mathrm{~mm}$ per tahun; intensitas hujan dan banjir meningkat; frekuensi kekeringan dan erosi meningkat; dan fenomena cuaca ekstrim (EI Nino, La Nina, siklon, puting beliung, dan hailstone) juga meningkat. Perubahan iklim sangat memengaruhi tata air/ sumberdaya air (Runtunuwu \& Syahbuddin, 2007) dan pertanian serta ketahanan pangan (Challinor et al., 2007; Kang, et al., 2009). 
Menurut kajian Syahbuddin et al. (2004) pada 13 stasiun Klimatologi di Indonesia, menunjukkan telah terjadi perubahan iklim, di Indonesia bagian timur terdapat tendensi peningkatan jumlah curah hujan tahunan berkisar antara $490 \mathrm{~mm}$ per tahun (Sulawesi Selatan) hingga $1400 \mathrm{~mm}$ per tahun (Jawa Timur) dan suhu siang dan malam hari meningkat antara $0,5-1,1^{\circ} \mathrm{C}$ dan $0,6-2,3^{\circ} \mathrm{C}$. Namun, sebaliknya di Indonesia bagian barat terdapat tendensi penurunan curah hujan tahunan sekitar $135 \mathrm{~mm}$ per tahun hingga $860 \mathrm{~mm}$ per tahun dan suhu siang dan malam hari meningkat antara $0,2-0,4{ }^{\circ} \mathrm{C}$ dan $0,2-0,7{ }^{\circ} \mathrm{C}$. Sejalan dengan indikasi perubahan iklim tersebut, indikasi lainnya adalah makin cepatnya periode El-Nino yang terjadi di Indonesia yang semula terjadi setiap 5-6 tahun sekali berubah menjadi 2-3 tahun sekali (Aldrian, 2007; Runtunuwu \& Kondoh, 2008).

Sektor pertanian sangat rentan terhadap dampak perubahan iklim karena aktivitasnya sangat tergantung pada kondisi cuaca dan iklim. Selain itu orang yang bermata pencaharian di sektor pertanian cenderung lebih miskin dibandingkan dengan orang-orang yang bekerja pada sektor lain di kota (Aggarwal, 2008; Jin \& Zhu, 2008; Kang et al., 2009).

Indonesia yang merupakan wilayah agraris, perubahan iklim (hujan) merupakan ancaman terbesar, karena banyak kegiatan pertanian di sawah sangat tergantung pada hujan, setiap perubahan curah hujan dapat menimbulkan resiko besar (Ruminta, 2016). Sistem pertanian pada lahan tadah hujan sangat rentan terhadap perubahan iklim, jika teknik budidayanya tidak berubah (Ruminta et al., 2009). Peningkatan suhu akan mengganggu proses fisiologi tanaman. Suhu tinggi selama fase kritis menggangu perkembangan dan proses berbunga tanaman. Suhu tinggi ditambah dengan kekeringan menyebabkan bencana besar pada lahan pertanian. Peningkatan suhu dan kelembaban juga dapat mendorong ledakan hama dan penyakit tanaman. Bencana kekeringan dan banjir dapat menurunkan produksi pertanian. Kekeringan dan banjir yang berkepanjangan akibat perubahan iklim dan pengelolaan tata air yang tidak baik sehingga kapasitas air tanah terlalu rendah atau terlalu tinggi menyebabkan produksi padi turun secara signifikan (Ruminta \& Handoko, 2016).

Kajian dampak dari perubahan iklim terhadap pertanian dapat dikaji melalui analisis tingkat potensi bahaya (hazard), kerentanan (vulnerability) dan risiko (risk) (Metternicht et al., 2014; Wolf, 2012). Bahaya yakni bahaya dari perubahan iklim yaitu potensi penurunan produksi pertanian sebagai akibat penurunan produktivitas, gagal panen, gagal tanam, dan berkurangya luas lahan pertanian. Sedangkan kerentanan adalah kemampuan petani atau kelompok tani dalam mengantisipasi, menanggulangi, mempertahankan, dan menyelamatkan diri secara alami dari dampak yang ditimbulkan oleh bahaya (hazard) yaitu perubahan iklim. Risiko adalah besarnya risiko yang ditimbulkan oleh perubahan iklim tersebut terhadap penurunan produksi pertanian yang berimplikasi terhadap pasokan pangan dan ketahanan pangan. Analisis risiko penurunan produksi pertanian yang rentan terhadap ancaman bahaya perubahan iklim dilakukan menggunakan pendekatan kuantitatif agar dapat dilakukan prediksi dan antisipasinya.

Informasi tingkat risiko dampak perubahan iklim dapat dipergunakan sebagai bahan pertimbangan dalam penyusunan pedoman untuk melakukan 
adaptasi dan antisipasi pada tingkat lokal (Reid et al., 2007; Runtunuwu et al., 2011). Mengingat hal tersebut, diperlukan informasi mengenai indikasi perubahan iklim yang akurat dan bagaimana dampaknya terhadap penurunan produksi pertanian di wilayah tersebut sebagai masukan untuk melakukan adaptasi strategis sehingga penurunan lebih lanjut produksi pertanian dapat dicegah. Tulisan ini dimaksudkan untuk menyediakan informasi mengenai indikasi perubahan iklim dan dampaknya terhadap penurunan produksi padi di wilayah Indonesia.

\section{BAHAN DAN METODE}

Penelitian ini dilakukan di wilayah Propinsi Sumatera Selatan dan Malang raya Jawa Timur. Metode pengumpulan data menggunakan survei, observasi, dan arsip. Penelitian ini menggunakan data suhu udara, curah hujan, luas tanam, luas panen, produktivitas dan produksi tanaman pertanian, luas jaringan irigasi, ketinggian tempat, tata guna lahan pertanian, dan data sosial ekonomi. Data tersebut digunakan untuk mengidentifikasi perubahan iklim dan mengkuantifikasi besarnya potensi penurunan produksi tanaman pangan.

Metode analisis data yang digunakan dalam penelitian ini adalah deskriptif eksplanatif yang merupakan jenis analisis gabungan kuantitatif dan kualitatif (Kothari, 2004). Tahapan analisis yang dilakukan dalam penelitian ini adalah analisis perubahan iklim untuk mengidentifikasi adanya perubahan iklim. Tahap berikutnya adalah analisis penurunan produksi tanaman padi akibat dari perubahan iklim. Analisis penurunan produksi tanaman padi dilakukan menggunakan model empirik dengan konsep Hazard dan Risk Assessment seperti ditunjukkan pada Gambar 1 dan 2.

Analisis data dalam penelitian ini menggunakan software statistik yaitu Minitab 16 untuk mendapatkan besarnya perubahan iklim dan penurunan produksi tanaman pertanian. Tingkat penurunan produksi tanaman pertanian disajikan dalam bentuk peta spasial menggunakan software GIS.

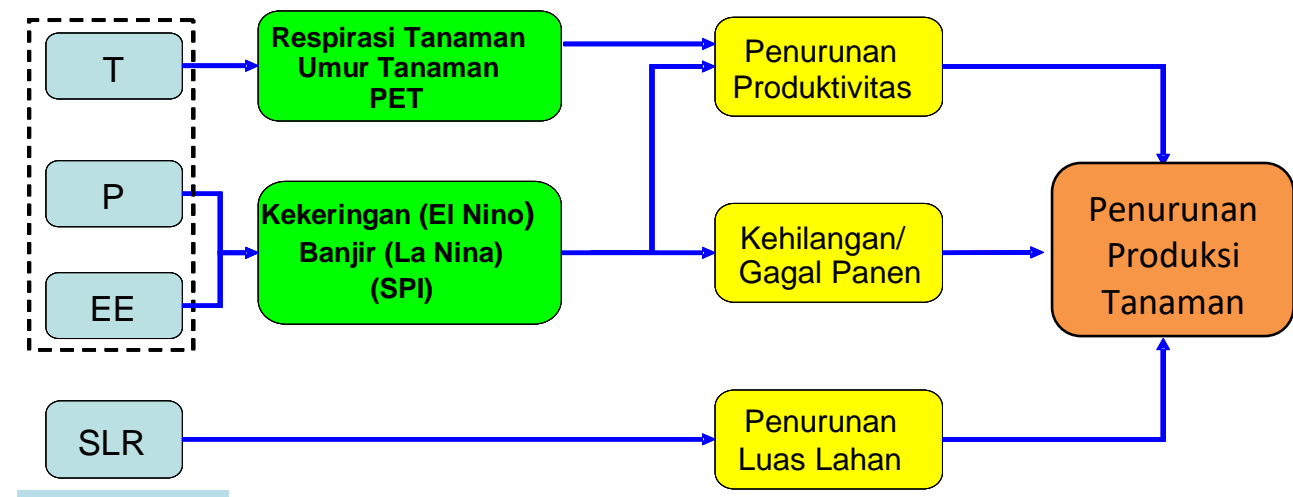

\section{STIMULI KLIMATIS}

\section{Bahaya (Hazard)}

$\mathrm{T}$ : Suhu (Temperature)

SPI : Standarized Precipitation Index

SLR : Kenaikan muka air laut (Sea Level Rise)

\section{$\mathrm{P}:$ Hujan (Precipitation)}

EE : Kejadian cuaca ekstrim (Extreme Event)

PET : Evapotranspirasi potensial (Potential Evapotranspiration)

Gambar 1. Diagram alir analisis bahaya (hazard) potensi penurunan produksi tanaman pertanian akibat perubahan iklim (Ruminta \& Handoko, 2012) 


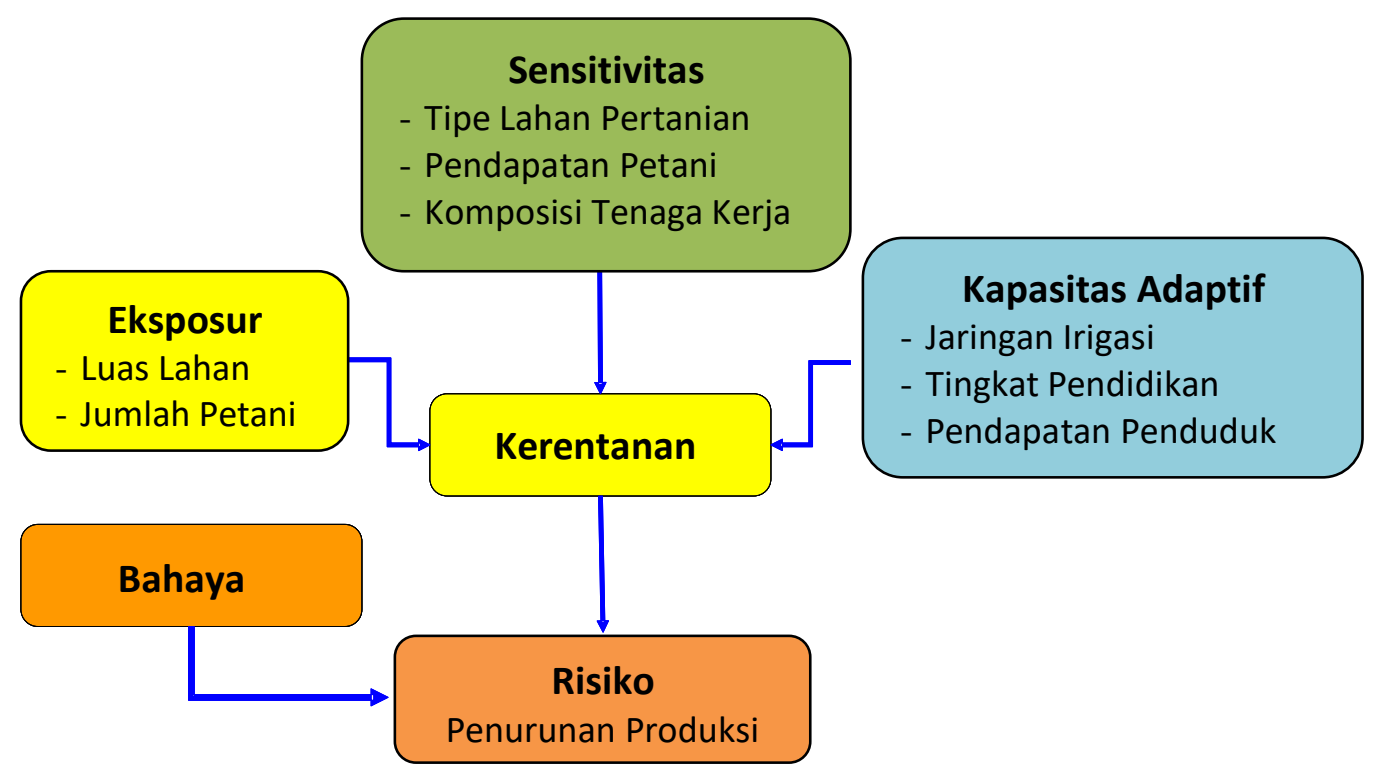

Gambar 2. Diagram alir analisis kerentanan dan risiko perubahan iklim pada produksi padi (Ruminta \& Handoko, 2016)

\section{HASIL DAN PEMBAHASAN}

\section{Indikasi Perubahan Iklim}

Hasil kajian menunjukkan bahwa di wilayah Indonesia telah mengalami perubahan iklim yang ditunjukkan dengan berubahnya pola curah hujan dan hari hujan, serta kecenderungan menurunnya curah hujan tahunan dan distribusi curah hujan. Hasil ini sejalan dengan yang diindikasikan dari penelitian Syahbuddin et al. (2004) dan Aldrian (2007) bahwa di beberapa wilayah Indonesia telah mengalami perubahan iklim. Di beberapa wilayah ada indikasi kenaikan suhu udara, perubahan pola distribusi curah hujan bulanan dan tahunan, klasifikasi iklim, dan hitergraf. Perubahan iklim di wilayah Indonesia telah terjadi dan menimbulkan ancaman besar bagi sistem pertanian (terutama tanaman padi) seperti yang telah ditunjukkan oleh hasil penelitian Ruminta \& Handoko (2016).
Hasil kajian menemukan bahwa di beberapa wilayah Sumatera Selatan telah terjadi peningkatan suhu udara sebesar 0,4$0,6^{\circ} \mathrm{C}$ (Gambar 3). Curah hujan menurun sebesar 0-197 mm (Gambar 4). Adanya peningkatan suhu udara dan penurunan curah hujan tersebut menyebabkan perubahan klasifikasi Oldeman dan hitergraf yaitu wilayah tersebut yang cenderung bersifat lebih kering (Gambar 5 dan 6). Ada lima wilayah yang mengalami perubahan tipe Klasifikasi Oldeman yaitu Kabupaten Musi Rawas (B1 menjadi D1), Musi Banyuasin (B1 menjadi D1), East OKU (C2 menjadi $\mathrm{C} 1$ ), Ogan Ilir (C2 menjadi $\mathrm{C} 1$ ), dan OKI (C1 dan C2 menjadi B1).

Sementara itu hasil kajian di Wilayah Malang Raya Jawa Timur menunjukkan bahwa suhu udara meningkat yaitu sebesar $0,7-0,8^{\circ} \mathrm{C}$ dan curah hujan menurun sekitar 0-550 $\mathrm{mm}$. Hitergraf di wilayah tersebut juga mengalami pergeseran. Sama halnya dengan klasifikasi Oldeman mengalami pergeseran dari kelas C3 menjadi C2. 
Perubahan tipe klasifikasi iklim Oldeman tersebut sangat mempengaruhi terhadap ketersediaan air, masa pertumbuhan (growing season), awal tanam, dan jenis tanaman yang dapat dibudidayakan di wilayah tersebut.

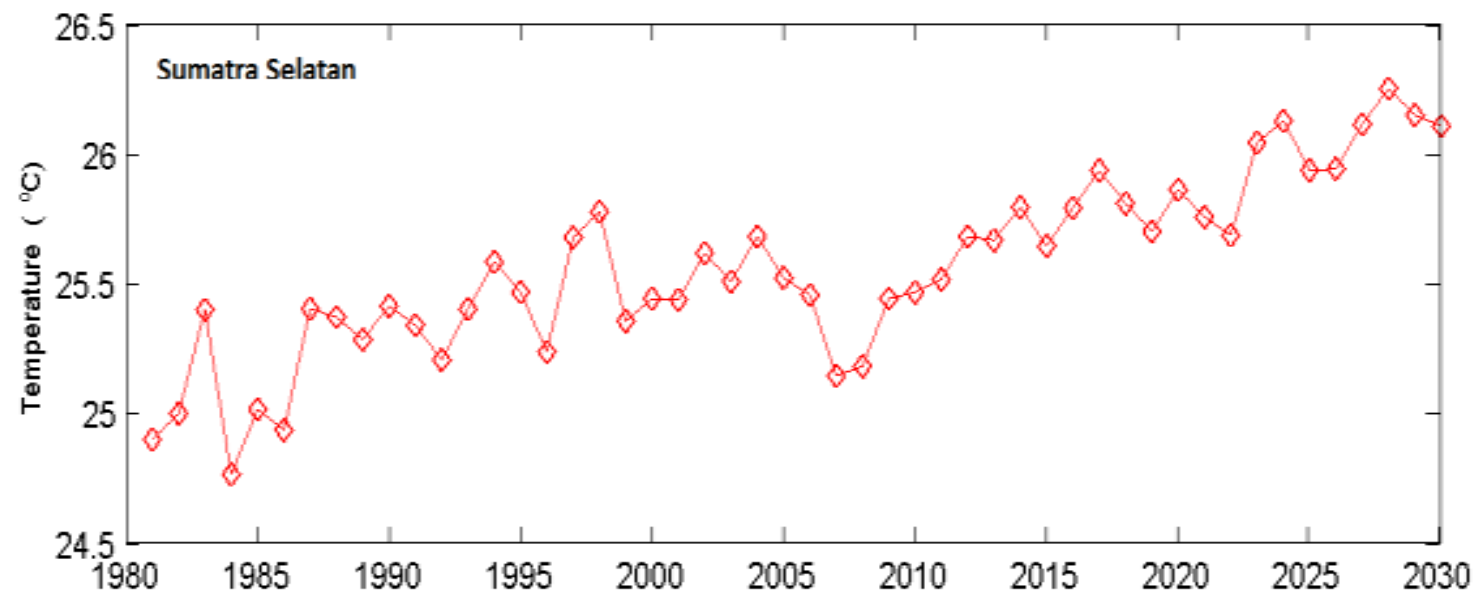

(3a)

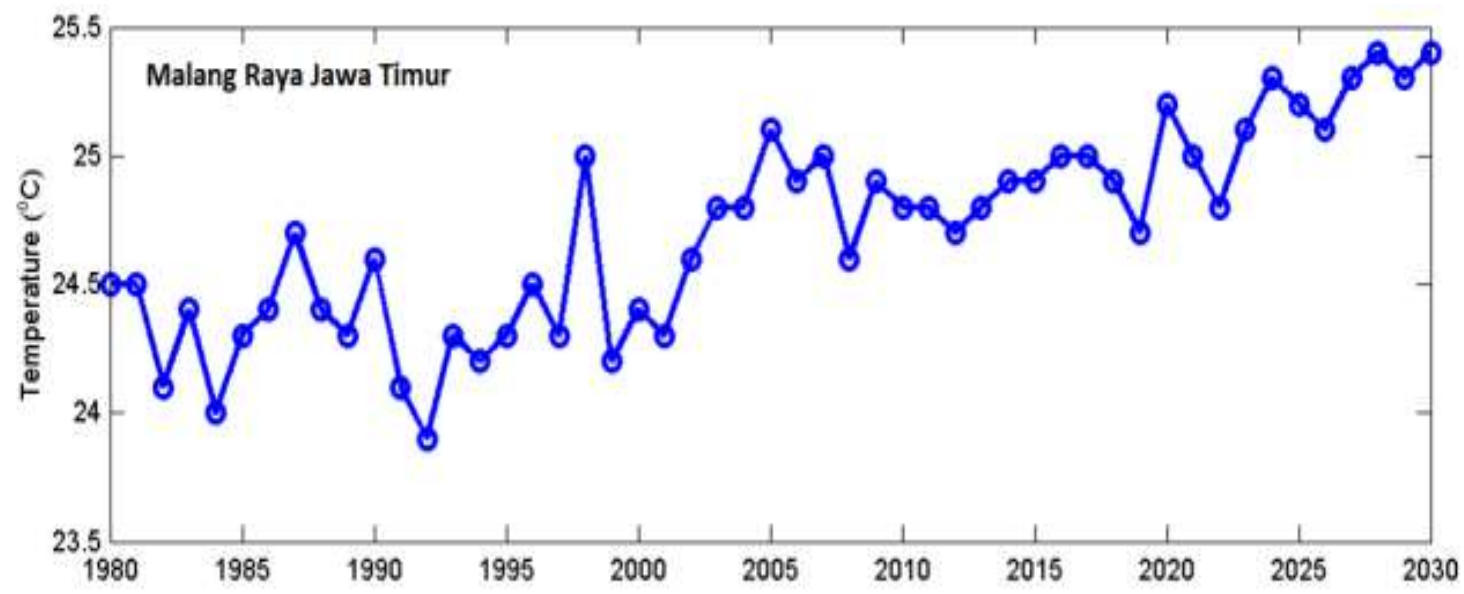

(3b)

Gambar 3. Pola suhu udara (temperature): a) Sumatra Selatan b) Malang Raya

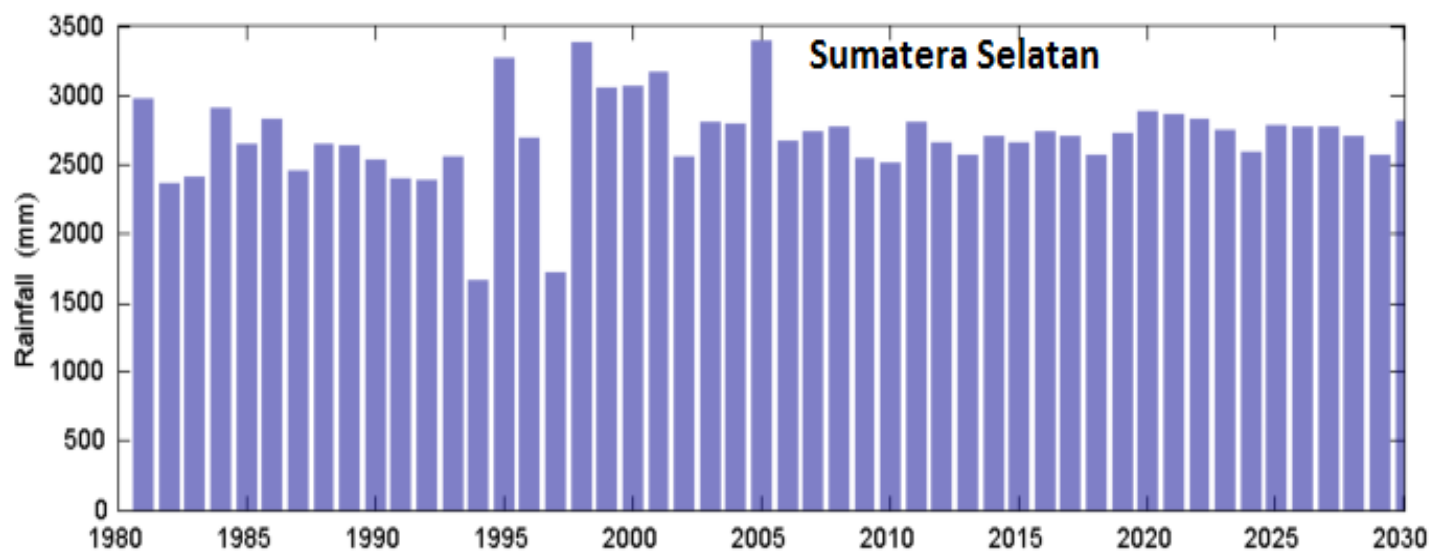

(4a) 


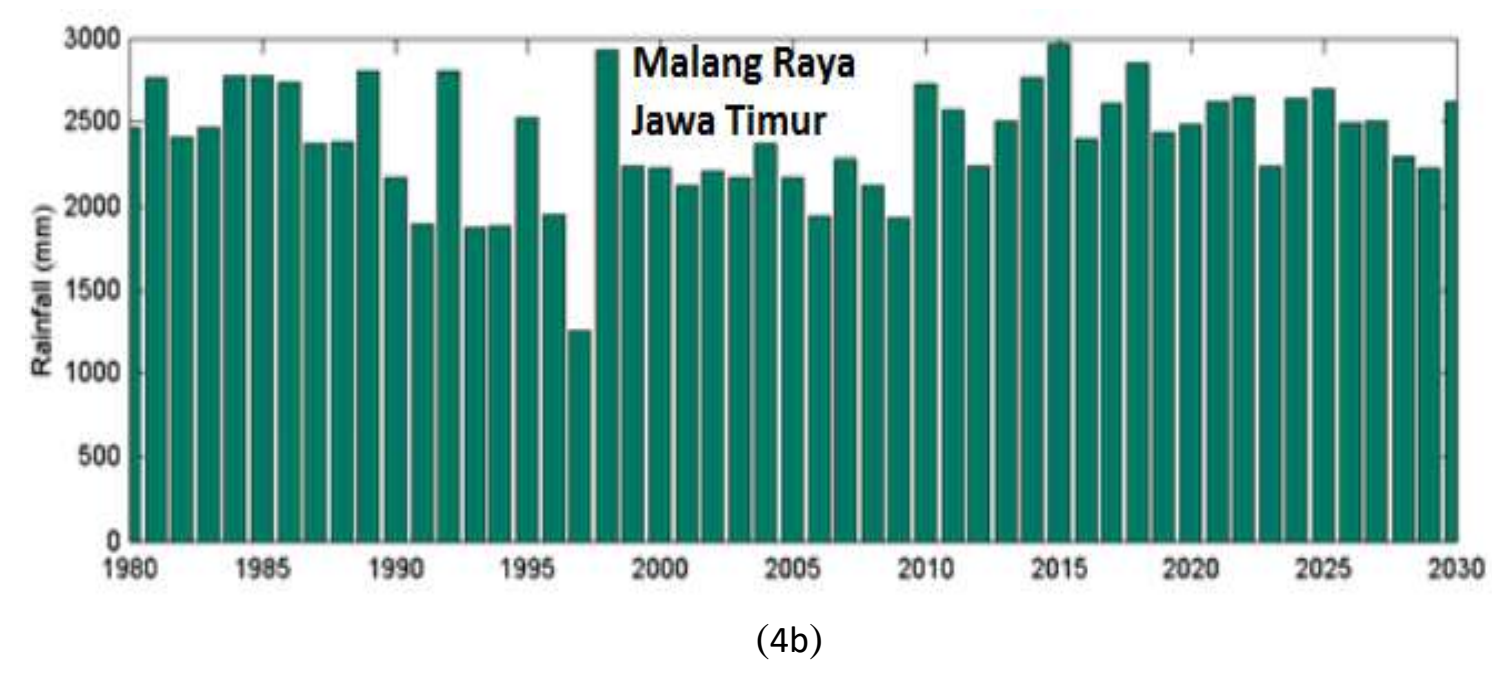

Gambar 4. Pola curah hujan (rainfall) tahunan: a) Sumatera Selatan b) Malang Raya
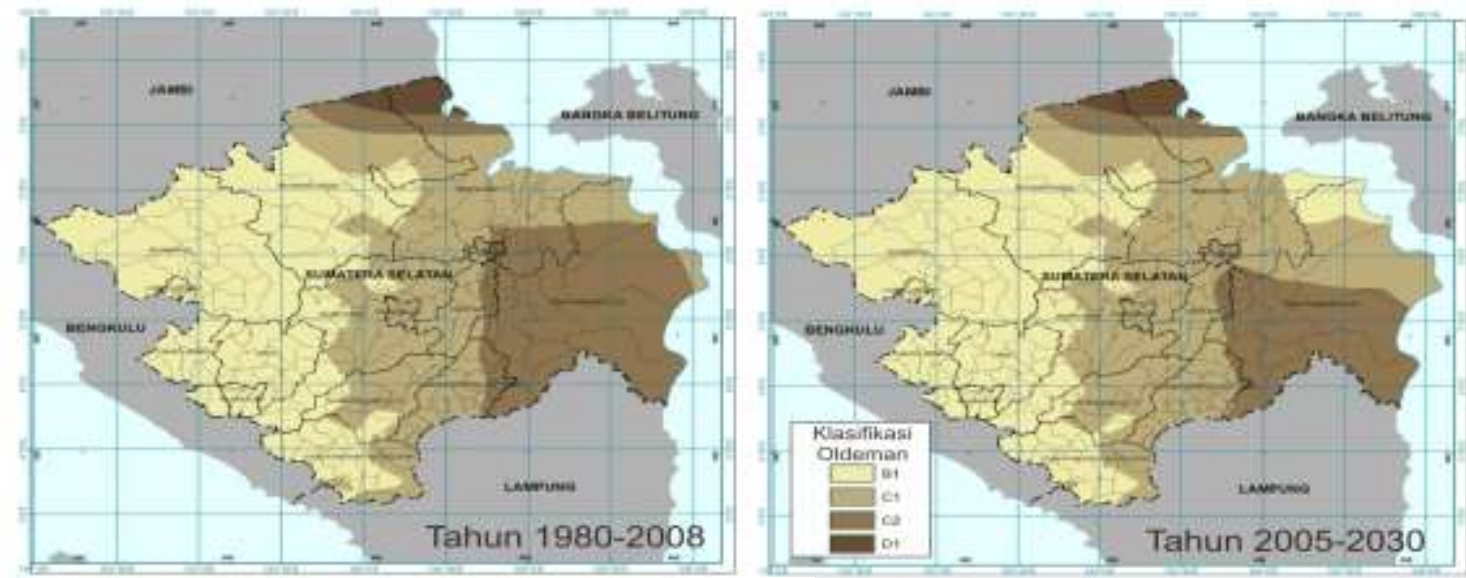

(5a)

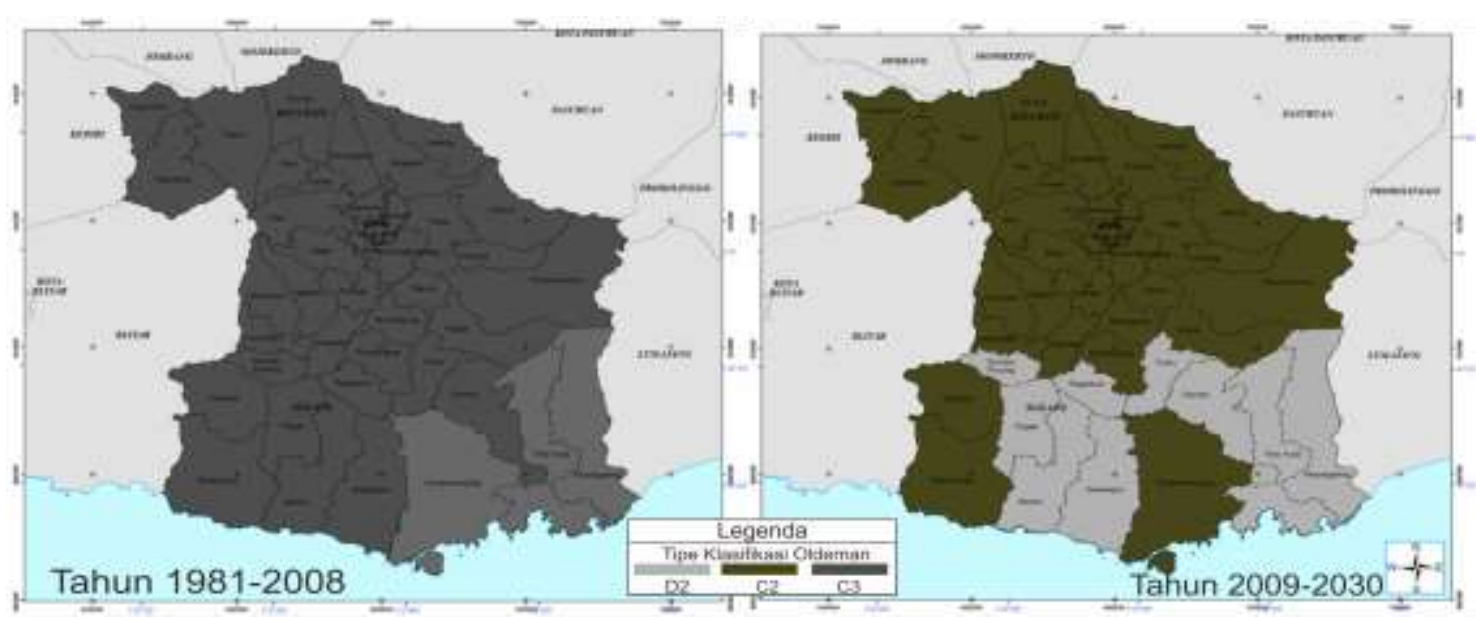

(5b)

Gambar 5. Perubahan klasifikasi iklim: a) Sumatera Selatan b) Malang Raya 


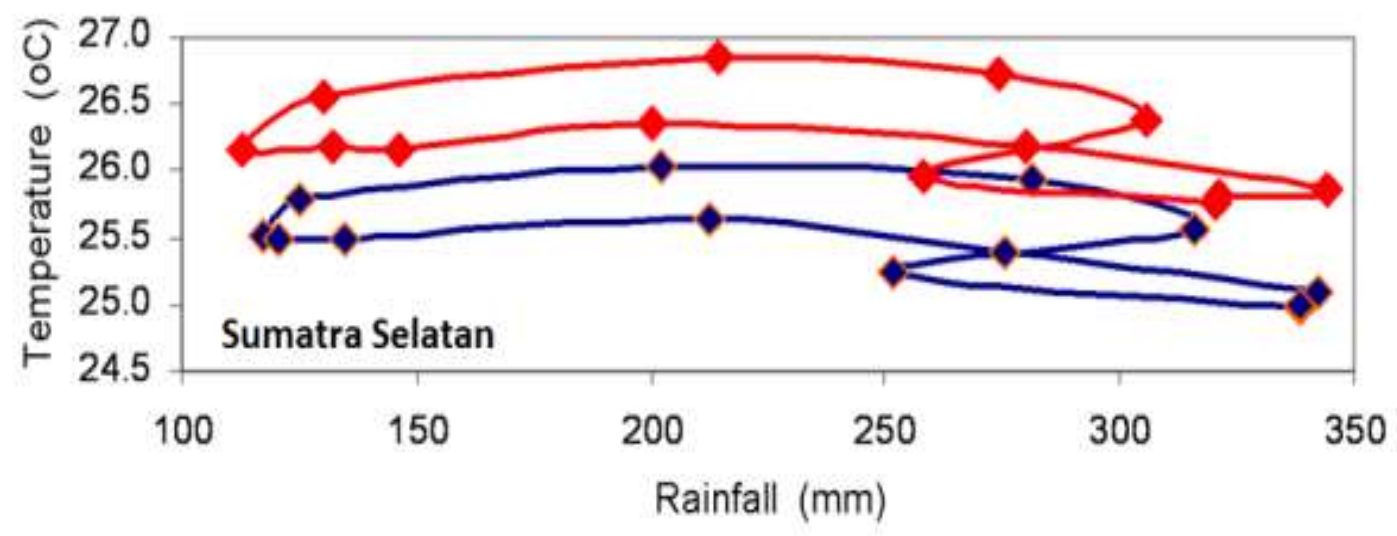

(6a)

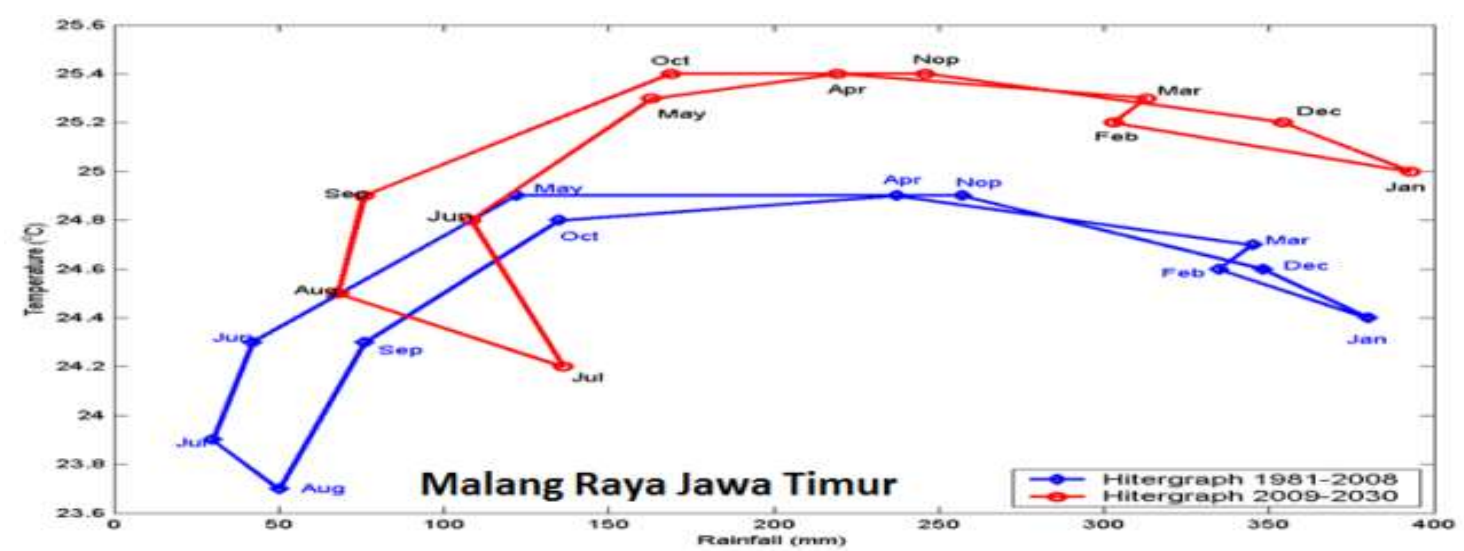

(6b)

Gambar 6. Perubahan Hitergraf: a) Sumatera Selatan b) Malang Raya

\section{Dampak Perubahan Iklim Terhadap Produksi Tanaman Padi}

Hasil penelitian menunjukkan bahwa wilayah Sumatera Selatan mempunyai tingkat kerentanan akibat perubahan iklim pada level sangat tinggi karena lahan pertaniannya didominasi lahan non irigasi dan rawa. Demikian juga wilayah Malang Raya mempunyai tingkat kerentanan pada level hingga sangat tinggi karena wilayah tersebut mempunyai lahan pertanian luas tetapi infrastruktur irigasi sangat sedikit.

Hasil penelitian tentang tingkat risiko penurunan produksi padi di Sumatera Selatan menunjukkan sebagian besar wilayah tersebut mempunyai tingkat risiko rendah, kecuali di Kabupaten Ogan Komering Ulu Timur mempunyai tingkat risiko penurunan produksi padi pada level tinggi (Gambar 7 dan 8). Umumnya Sumatera Selatan mempunyai tingkat risiko tinggi pada penurunan produksi padi dengan rerata $1,37 \%$ per tahun. Sementara itu tingkat risiko penurunan produksi padi di wilayah Malang Raya pada level tinggi terjadi di Kecamatan Pagelaran dan tingkat risiko penurunan produksi padi pada level sangat tinggi terjadi di Kecamatan Dampit, Turen, Kepanjen, dan Singosari. 


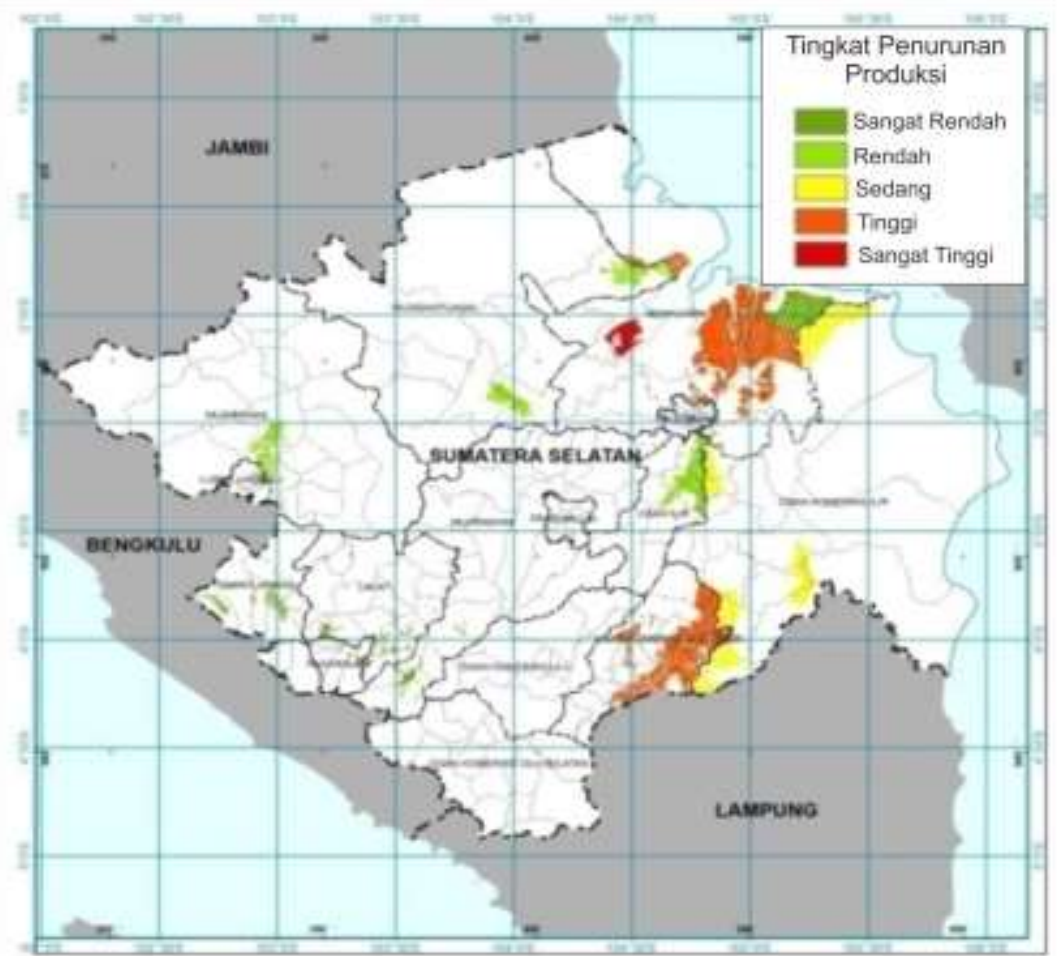

(7a)

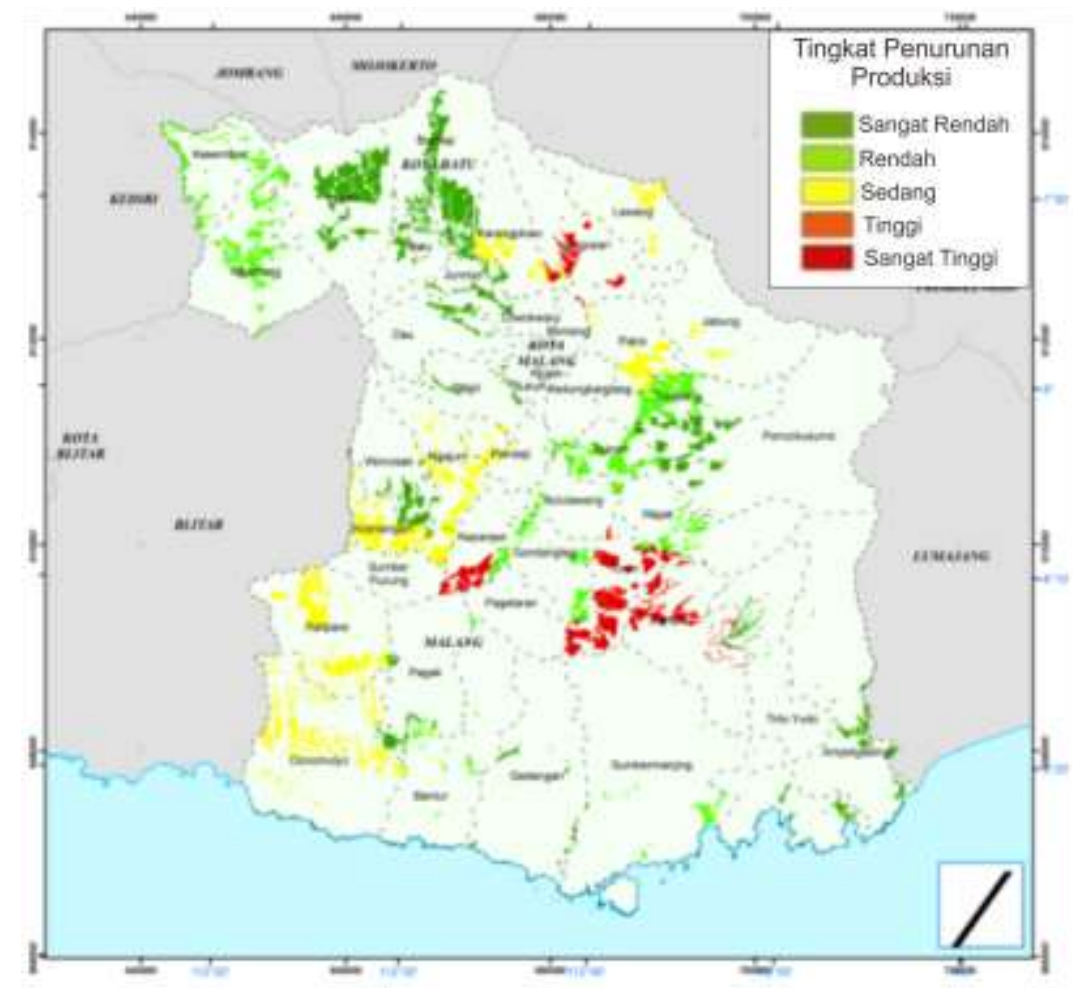

(7b)

Gambar 7. Potensi penurunan produksi padi sawah: a) Sumatera Selatan b) Malang Raya 


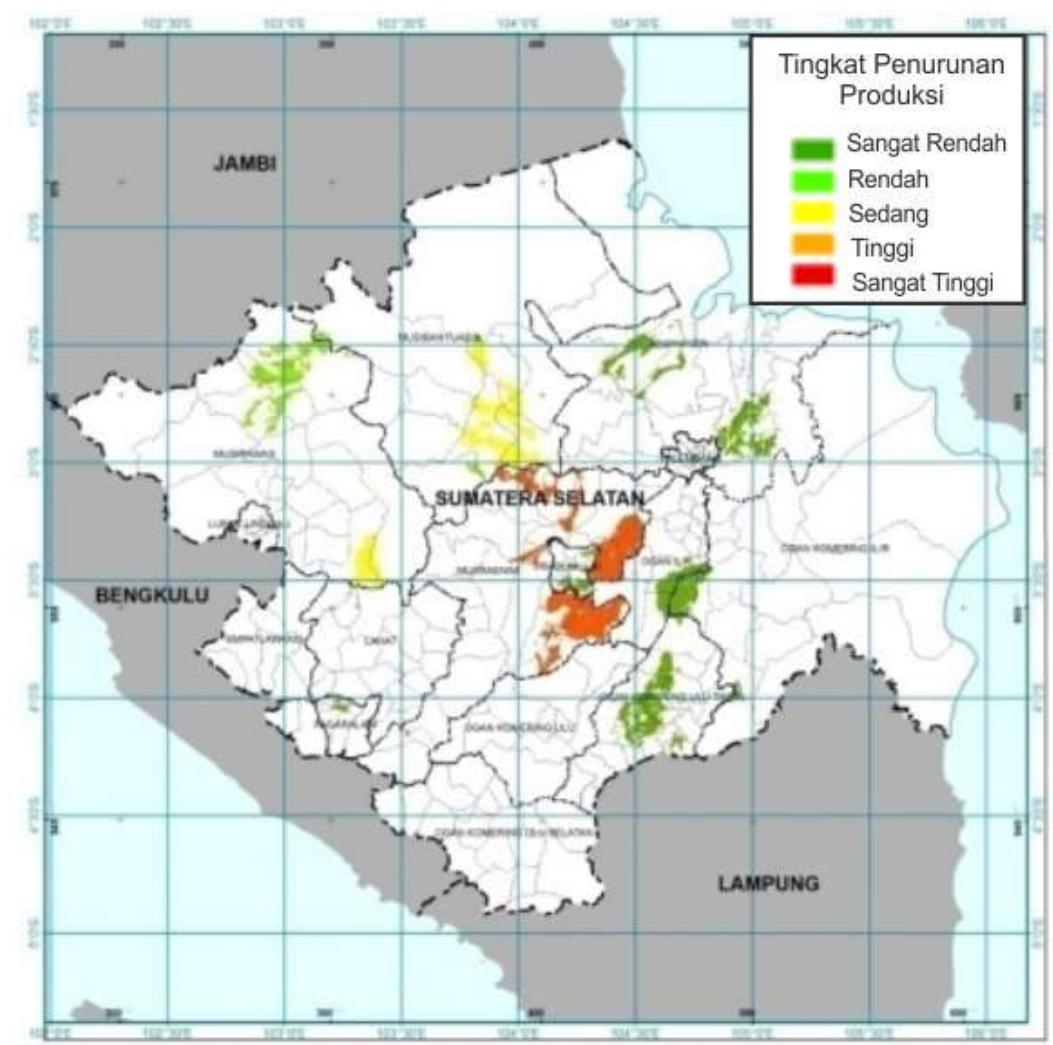

(8a)

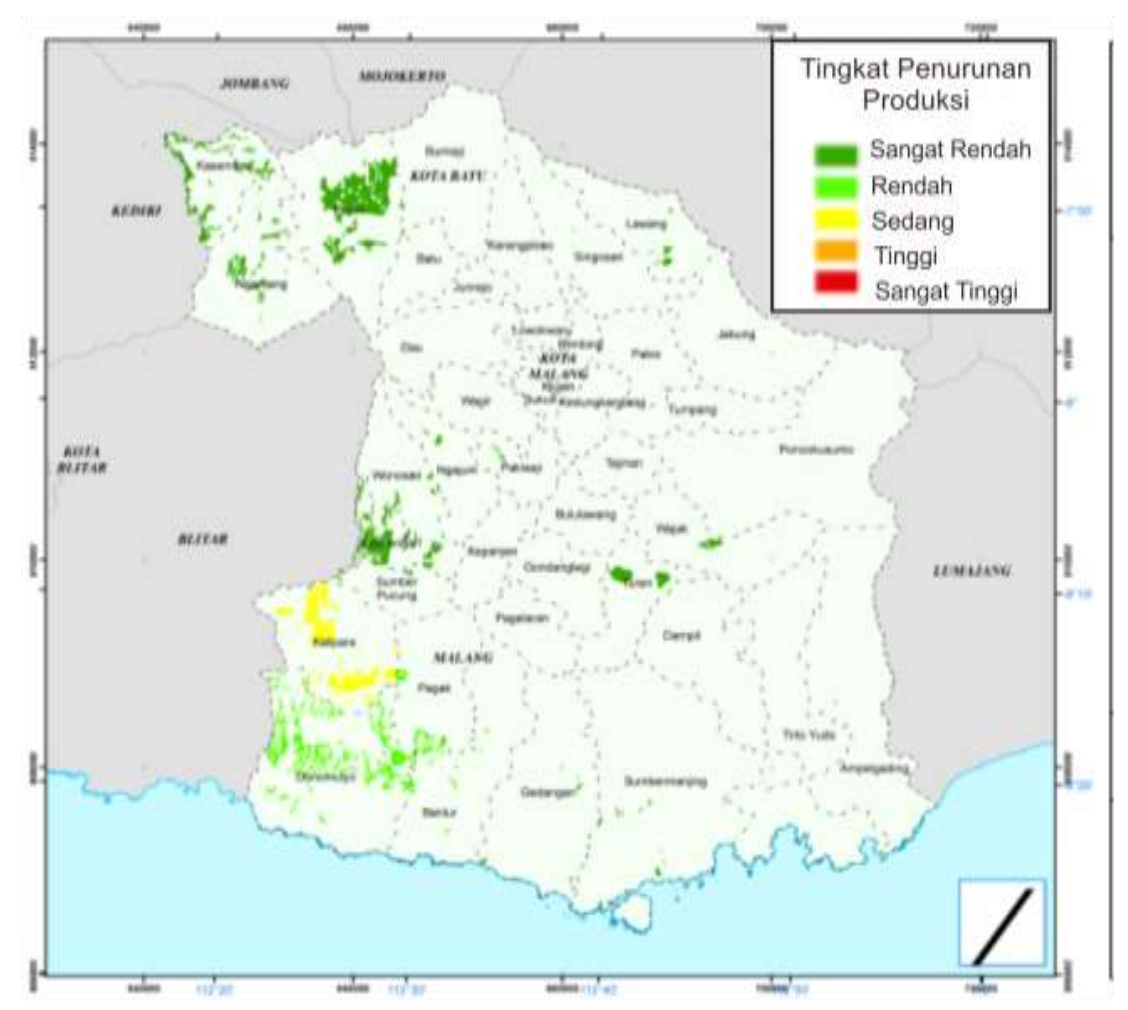

(8b)

Gambar 8. Potensi penurunan produksi padi lahan kering: a) Sumatera Selatan b) Malang Raya 
Hasil penelitian menunjukkan bahwa perubahan iklim cukup rentan terhadap penurunan luas panen dan produksi padi di Indonesia seperti ditunjukkan di Sumatera Selatan dan Malang Raya. Hasil analisis risiko penurunan produksi tanaman pertanian menunjukkan bahwa daerah yang mempunyai potensi penurunan tinggi dari hasil pertanian akibat perubahan iklim adalah OKU Timur (padi sawah) dan Muara Enim (padi lahan kering). Berdasarkan hasil penelitian juga diketahui bahwa penurunan produktivitas tanaman padi di wilayah tersebut ratarata $0,59 \%$ dan $1,59 \%$ per tahun untuk masing-masing tanaman padi sawah dan padi lahan kering.

\section{SIMPULAN}

1. Indonesia telah mengalami perubahan iklim dengan indikasi peningkatan suhu, perubahan pola curah hujan, perubahan klasifikasi Oldeman, dan perubahan hitergraf.

2. Sistem pertanian tanaman pangan sangat rentan terhadap dampak perubahan iklim dengan indikasi tingkat bahaya yang tinggi pada penurunan produksi padi akibat peningkatan suhu dan perubahan pola curah hujan.

3. Beberapa daerah di Sumatera Selatan maupun Malang Raya mempunyai risiko tinggi pada penurunan produksi tanaman padi.

4. Indonesia mempunyai potensi tingkat risiko tinggi pada penurunan produksi padi sekitar $1,37 \%$ per per tahun.

5. Indonesia harus melakukan adaptasi strategis untuk mengantisipasi dan mencegah penurunan produksi tanaman padi.

\section{DAFTAR PUSTAKA}

Aggarwal, P, K. (2008). Global climate change and Indian agriculture: impacts, adaptation and mitigation. Indian Journal of Agricultural Sciences, 78(11), 911-919. Retrieved from http://epubs.icar.org.in/ejournal/index.p hp/IJAgS/article/view/10332/4734

Aldrian, E. (2007). Decreasing trends in annual rainfalls over Indonesia: A threat for the national water resource?. Jakarta: Badan Meteorology dan Geofisika. Retrieved from https://scholar.google.com/scholar?oi=b ibs\&cluster $=2604969414494181069 \&$ btn $\mathrm{l}=1 \& \mathrm{hl}=\mathrm{id}$

Badan Pusat Statistik. (2014). Produksi Padi Menurut Provinsi (ton) Tahun 1993-2015.

Challinor, A., Wheeler, T., Garforth, C., Craufurd, P., \& Kassam, A. (2007). Assessing the vulnerability of food crop systems in Africa to climate change. Climatic Change, 83(3), 381-399. https://doi.org/10.1007/s10584-0079249-0

Government of Republic of Indonesia. (2007). Indonesia Country Report: Climate Variability and Climate Changes, and Their Implication. Jakarta: Ministry of Environment Republic of Indonesia.

Handoko, I. (2007). Relationship between crop developmental phases and air temperature and its effect on yield of the wheat crop (Triticum aestivum L.) grown In Java Island, Indonesia. BIOTROPIA, 14(1), 51-61. http://dx.doi.org/10.11598/btb.2007.14. 1.24

IPCC. (2007): Climate Change 2007: Impacts, Adaptation and Vulnerability. Contribution of Working Group II to the Fourth Assessment Report of the Intergovernmental Panel on Climate Change, M.L. Parry, O.F. Canziani, J.P. Palutikof, P.J. van der Linden and C.E. Hanson (Eds). , Cambridge, UK: Cambridge University Press. 976pp. 
Jin, Z. Q., \& Zhu, D. W. (2008). Impacts of Changes in Climate and Its Variability on Food Production in Northeast China. Acta Agronomica Sinica, 34(9), 15881597. https://doi.org/10.1016/S18752780(09)60005-5

Kang, Y., Khan, S., \& Ma, X. (2009). Climate change impacts on crop yield, crop water productivity and food security - A review. Progress in Natural Science, 19(12), 1665-1674.

https://doi.org/10.1016/j.pnsc.2009.08.0 01

Kothari, C. (2004). Research methodology: methods and techniques. New Delhi, India: New Age International.

Manton, M. J., Haylock, M. R., Hennessy, K. J., Nicholls, N., Chambers, L. E., Collins, D. A., \& Yee, D. (2001). Trends in Extreme Daily Rainfall and Temperature in Southeast Asia and the South Pacific: 1961 - 1998, 284, 269-284. https://doi.org/10.1002/joc.610

Masutomi, Y., Takahashi, K., Harasawa, H., \& Matsuoka, Y. (2009). Impact assessment of climate change on rice production in Asia in comprehensive consideration of process/parameter uncertainty in general circulation models. Agriculture, Ecosystems and Environment, 131(3-4), 281-291.

https://doi.org/10.1016/j.agee.2009.02. 004

Metternicht, G., Sabelli, A., \& Spensley, J. (2014). Climate change vulnerability, impact and adaptation assessment lessons from Latin America. International Journal of Climate Change Strategies and Management, 6(4), 442-476. https://doi.org/10.1108/IJCCSM-062013-0076

Naylor, R. L., Battisti, D. S., Vimont, D. J., Falcon, W. P., \& Burke, M. B. (2007). Assessing risks of climate variability and climate change for Indonesian rice agriculture. Proceedings of the National Academy of Sciences of the United States of America, 104(19), 7752-7. https://doi.org/10.1073/pnas.07018251
04

Reid, S., Smit, B., Caldwell, W., \& Belliveau, S. (2007). Vulnerability and adaptation to climate risks in Ontario agriculture. Mitigation and Adaptation Strategies for Global Change, 12(4), 609-637. https://doi.org/10.1007/s11027-0069051-8

Ruminta. (2016). Analisis penurunan produksi tanaman padi akibat perubahan iklim di Kabupaten Bandung Jawa Barat. Jurnal Kultivasi, 15(1), 37-45.

Ruminta \& Handoko. (2012). Climate Risk and Adaptation Assessment of Agriculture Sector in the Great Malang East JavaSynthesis Report. Jakarta: Ministry of Environment.

Ruminta \& Handoko. (2016). Vurnerability assessment of climate change on agriculture sector in the South Sumatra province, Indonesia. Asian Journal of Crop Science, 8(2), 31-42. https://doi.org/10.3923/ajcs.2016.31.42

Ruminta, Nurmala, T., \& Kosim, W. A. (2009). Analisis Dampak Perubahan Pola Curah Hujan Terhadap Sistem Pertanian Tanaman Pangan Lahan Kering Di Jawa Barat. Laporan Penelitian Strategis Nasional. Direktorat Riset, Pengabdian pada Masyarakat dan Inovasi, Universitas Padjadjaran.

Runtunuwu, E., I. Las, I. Amien, \& H. S. (2011). Utilizing Cropping Calendar in Coping With Climate Change. ECOLAB, 5(1), $1-14$ https://doi.org/10.20886/jklh.2011.5.1.1 $-14$

Runtunuwu, E., \& Kondoh, A. (2008). Assessing global climate variability and change under coldest and warmest periods at different latitudinal regions. $J$. Agric. Sci., 9(1), 7-18.

Runtunuwu, E., \& Syahbuddin, H. (2007). Perubahan Pola Curah Hujan dan Dampaknya Terhadap Periode Masa Tanam. Tanah dan Iklim, 26(1), 1-12.

Syahbuddin, H., Manabu, D., Yamanaka, \& 
Runtunuwu, E. (2004). Impact of climate change to dry land water budget in Indonesia: observation during 1980-2002 and simulation for 2010-2039. Kobe: Kobe University Press.

UNFCCC. (2007). Climate Change: Impacts, Vulnerabilities and Adaptation in Developing Countries. United Nations Framework Convention on Climate
Change, 68 pp. Retrieved from https://unfccc.int/resource/docs/publica tions/impacts.pdf

Wolf, S. (2012). Vulnerability and risk: Comparing assessment approaches. Natural Hazards, 61(3), 1099-1113. https://doi.org/10.1007/s11069-0119968-4 